I respect the staff a great deal and am grateful to them for allowing me to share their experiences with them.

\section{Acknowledgements}

Many thanks to all the staff at the nursery and to Dr Sebastian Kraemer who supervised the work and helped keep me on the right track.

\section{References}

Brrtron, R. (1976) Consultations in Child Care. Tavistock Clinic, Document No. EN 1654.

Caplan, G. (1964) Principles of Preventive Psychiatry, London: Tavistock Publications.

OBHOLZER, A. (1987) The Assessment Process in the Work of Consulting to Institutions. Tavistock Clinic Paper No. 70.

\title{
Doctors' attitudes to male homosexuality: a survey
}

\author{
Dinesh Bhugra, Senior Registrar, Maudsley Hospital, Denmark Hill, London SE5
}

The topic of homosexuality has often aroused strong opinions among the public and professionals alike. In a study organised by the journal Modern Medicine in $1969,17,741$ physicians in the USA responded to a questionnaire. Of those who stated their speciality, $8 \%$ were psychiatrists, $26 \%$ general practitioners and $10 \%$ general surgeons. Questions sought opinions on abortion, legalisation of marijuana, legalisation of homosexual practice and other topics; $92 \%$ of psychiatrists $[n 2,041]$ were in favour of legalising homosexual practices. The three specialities least in favour were general practitioners $59 \%$ [ $n$ $6,927$, general surgeons $59 \%$ [ 2,580$]$ and orthopaedic surgeons $58 \%$ [ $n$ 731]. The sample was selfselected and this may have introduced a respondent bias. The data were collected nearly 20 years ago when homosexuality was still seen as a psychiatric illness in the American Psychiatric Association's Diagnostic and Statistical Manuals I and II.

A study in the UK in 1973 by Morris used a postal questionnaire to enquire into the attitudes of 150 general practitioners and 150 psychiatrists selected at random. Psychiatrists were more likely to see homosexuality as inborn with development in infancy; $4 \%$ of general practitioners and $8 \%$ of psychiatrists saw homosexuality as a disease. In 1974 Barr \& Catts in Australia found that $35 \%$ of psychiatrists in their sample saw homosexuality as a neurotic illness, compared to $19 \%$ of psychiatric trainees. Attitudes of doctors to homosexuality may be expected to vary according to age, sex, cultural background, training, specialty, religion, etc. Psychiatry is affected by the cultural milieu within which it is embedded, reflecting the dominant values of the time and place and perhaps tending to challenge social values and practices.
Several studies have demonstrated that homosexuals fear to disclose their sexuality to their doctors (Maurer, 1975; Morton \& McManus, 1986), and that they also tend to feel that the medical profession is less geared towards their needs than to those of heterosexuals (Dardick \& Grady, 1980). Yet problems experienced by male homosexuals are determined in part by public attitudes and doctors are in some respects able to lead public opinion. Therefore it is of interest to inquire into doctors' attitudes towards homosexuality.

\section{The study}

The present study set out to investigate the attitudes of psychiatrists and general practitioners, the two groups most likely to be approached by homosexuals for medical help in issues concerning their sexuality. The study focused on male homosexuality because male homosexuals attract more attention and appear to arouse stronger feelings than female homosexuals.

A questionnaire was designed specifically for the study, though several items had been previously used by other authors. Respondents were asked to quantify their agreement or disagreement with a series of statements on a 5-point scale. The questionnaire was circulated with an explanatory letter and a Freepost envelope for replies to all the psychiatrists and the inceptors in the Midlands division of the Royal College of Psychiatrists [n 510] whose addresses had been obtained through the College. Questionnaires were sent to an equivalent number of general practitioners [GPs] from the same geographical area, randomly selected from Family Practitioner Committee lists. The 'strongly agree' and 'agree' responses were summated as were 'strongly disagree' 
TABLE I

\begin{tabular}{|c|c|c|c|c|}
\hline & & Agree & No opinion & Disagree \\
\hline I believe that male homosexuality is an illness & $\begin{array}{l}\text { Psychiatrists } \\
\text { GPS }\end{array}$ & $\begin{array}{r}8 \\
18\end{array}$ & $\begin{array}{c}11 \\
17 \\
P<0.005\end{array}$ & $\begin{array}{l}174 \\
123\end{array}$ \\
\hline Male homosexuals in general are neurotic & $\begin{array}{l}\text { Psychiatrists } \\
\text { GPs }\end{array}$ & $\begin{array}{l}43 \\
78\end{array}$ & $\begin{array}{c}52 \\
38 \\
P<0.00001\end{array}$ & $\begin{array}{r}136 \\
78\end{array}$ \\
\hline Male homosexuals in general are effeminate & $\begin{array}{l}\text { Psychiatrists } \\
\text { GPs }\end{array}$ & $\begin{array}{l}34 \\
71\end{array}$ & $\begin{array}{c}31 \\
26 \\
P<0.00001\end{array}$ & $\begin{array}{l}163 \\
103\end{array}$ \\
\hline Male homosexuals should not be employed in schools & $\begin{array}{l}\text { Psychiatrists } \\
\text { GPS }\end{array}$ & $\begin{array}{l}26 \\
80\end{array}$ & $\begin{array}{c}34 \\
29 \\
P<0.00001\end{array}$ & $\begin{array}{r}168 \\
87\end{array}$ \\
\hline Male homosexuals are a danger to children & $\begin{array}{l}\text { Psychiatrists } \\
\text { GPs }\end{array}$ & $\begin{array}{l}21 \\
65\end{array}$ & $\begin{array}{c}34 \\
18 \\
P<0.00001\end{array}$ & $\begin{array}{l}172 \\
113\end{array}$ \\
\hline $\begin{array}{l}\text { The subject of male homosexuality was adequately } \\
\text { covered in my medical school curriculum }\end{array}$ & $\begin{array}{l}\text { Psychiatrists } \\
\text { GPS }\end{array}$ & $\begin{array}{l}12 \\
12\end{array}$ & $\begin{array}{l}7 \\
7\end{array}$ & $\begin{array}{l}209 \\
179\end{array}$ \\
\hline I feel comfortable with male homosexuals & $\begin{array}{l}\text { Psychiatrists } \\
\text { GPS }\end{array}$ & $\begin{array}{r}149 \\
64\end{array}$ & $\begin{array}{c}54 \\
61 \\
P<0.00001\end{array}$ & $\begin{array}{l}26 \\
71\end{array}$ \\
\hline
\end{tabular}

and 'disagree', to give three-point responses to facilitate statistical analysis.

\section{Findings}

The response rates for usable questionnaires for psychiatrists and GPs were $45 \%$ and $39 \%$ respectively.

Table I shows the summarised responses of the two groups (using chi-square analyses).

\section{Comment}

Certain difficulties in interpreting these results must be acknowledged. The samples are not fully representative of psychiatrists and GPs; the response rates, usually poor with postal questionnaires, are even lower than expected, perhaps because of the sensitivity of the subject. Some extreme responses have been diluted in order to facilitate statistical analysis. The attributional factors for these attitudes have been ignored.

A better response could perhaps have been obtained by sending reminders. But it was necessary to preserve anonymity, and a more elaborate design was proscribed by financial constraints. Psychiatrists' higher response rate may be a reflection of their feeling more comfortable than GPs with homosexuals, as strikingly shown in the investigation. Overall the GPs were less accepting and showed more stereotyped attitudes. Psychiatrists were less likely to see homosexuality as an illness but this particular statement had the largest number of missing responses, namely $16 \%$ for psychiatrists and $20 \%$ for GPs.

It might well be predicted that those psychiatrists and GPs who chose to respond to the questionnaire would be those with strong opinions one way or the other but the numbers of missing responses and no opinion suggest a dissonance in their acts and actual responses.

GPs were much more likely to see male homosexuals as a danger to children, hence their strong response to the question of homosexuals' employment in schools. It is likely that psychiatrists are better able to differentiate between paedophilia and homosexuality. Commonly held stereotypes elicited by Dressler (1979) included homosexuals being a danger to children and also being generally neurotic. Psychiatrists by virtue of their training may be interpreting the word neurotic in a specific rather than a pejorative sense. The present sample has only $19 \%$ of psychiatrists regarding homosexuals as neurotic compared to $35 \%$ of Barr \& Catts' sample. However, the present sample makes no distinction between trainees and trained psychiatrists. Also the cross-cultural comparisons may not be entirely valid. Subsequent studies need to avoid the use of vague or ambiguous terms. 
GPs saw homosexuals as effeminate - another of Dressler's stereotypes. There is no clinical evidence to suggest that such is the case. It would have been useful to have included a question about the degree of contact the individual doctor had had with a homosexual. Both groups agreed overwhelmingly with the statement that the subject had not been adequately covered in their medical school curriculum.

The present study shows some of the attitudes prevalent among the medical profession before the Human Immunodeficiency Virus [HIV] became recognised in the UK. A study is currently under way to investigate the attitudes since the AIDS epidemic became established. The questionnaire needs to be validated with interviews for subsequent use. The attitudes in the present survey may provide a baseline which can be checked regularly in association with attributional factors for these beliefs.

\section{Acknowledgements}

I would like to thank Professor S. Brandon and Dr R. L. Palmer, Leicester University, for their help in the project. Thanks also to all the respondents for their replies and comments. Grateful thanks are also due to Professor R. H. Cawley at the Institute of Psychiatry for his comments on earlier drafts of the manuscript.

\section{References}

Anon (1969) The Modern Medicine poll on socio-medical issues. Modern Medicine, 37, 18-25.

BARR, R. F. \& CATTS, S. V. (1974) Psychiatric opinion and homosexuality: a short report. Journal of Homosexuality, 213-215.

DARDICK, L. \& GRADY, K. E. (1980) Openness between gay persons and health professionals. Annals of International Medicine, 93, 115-119.

DRESSLER, J. (1979) Study of law students' attitudes regarding the rights of gay people to be teachers. Journal of Homosexuality, 4, 315-329.

MAURER, T. B. (1975) Health care and the gay community. Postgraduate Medicine, 58, 127-130.

MoRRIS, P. A. (1973) Doctors' attitudes to homosexuality. British Journal of Psychiatry, 122, 435-436.

Morton, A. D. \& MCMANUs, I. C. (1986) Attitudes to and knowledge of the Acquired Immune Deficiency Syndrome; lack of a correlation. British Medical Journal, 293, 1212.

A full list of references is available from the author on request.

\title{
The University of Leicester new MRCPsych academic programme
}

\author{
Mervat NASSER, Senior Lecturer, University of Leicester and Consultant Psychiatrist, \\ South Lincolnshire Health Authority; and TraOlaCH BRUGHA, Senior Lecturer, \\ Department of Psychiatry, University of Leicester, Clinical Sciences Building, \\ Leicester Royal Infirmary, PO Box 65, Leicester LE2 7LX
}

Since the establishment of a separate Royal College of Psychiatrists and membership examination, psychiatry has been progressively acquiring a special identity of its own that bridges the social and biological sciences. The University of Leicester Psychiatric Training Scheme has responded to the recently revised Membership Examination by developing a two year modular academic programme, which complements the traditional medical (diagnostic) organisation of teaching by incorporating social and psychological views of the subject, which reflect the lessons of modern psychiatric research. It is hoped that the development of a more eclectic approach to the subject and its practice will complement the multidisciplinary and growing community orientation of the profession. We describe here our first attempts to provide an academic programme that responds sympathetically to these important developments.

\section{Background}

The first membership examination was held in 1972. It was closely modelled on the pattern of the diplomas in psychological medicine and remained so for almost a decade. In 1981, however, voices within 